\title{
Negative IgG Varicella Zoster Virus Antibody Status: Immune Responses Pre and Post Re-immunization
}

\author{
Tamar A. Smith-Norowitz • Tehila A. Saadia • Kevin B. Norowitz •
}

Rauno Joks · Helen G. Durkin · Stephan Kohlhoff

Received: October 28, 2017 / Published online: December 22, 2017

(C) The Author(s) 2017. This article is an open access publication

\begin{abstract}
Introduction: Varicella zoster virus (VZV) causes chicken pox and herpes zoster and is a selflimiting disease in healthy children. Vaccination is recommended for children, adolescents, and adults. This study discusses a healthy pediatric patient with negative immunoglobulin (Ig) G VZV antibody (Ab) status after two doses of varicella vaccine and then subsequently re-immunized. Since measurement of serum IgG titers alone may not reflect vaccine protection, we further evaluated cell-mediated and humoral immune responses before and after re-immunization.

Methods: Blood lymphocyte distributions (CD3+CD4+, CD3+CD8+, CD19+,
\end{abstract}

Enhanced content To view enhanced content for this article go to http://www.medengine.com/Redeem/ 8FFCF0600CB35E5F.

T. A. Smith-Norowitz $(\bowtie) \cdot$ T. A. Saadia

K. B. Norowitz · S. Kohlhoff

Division of Infectious Diseases, Department of

Pediatrics, State University of New York Downstate

Medical Center, Brooklyn, NY, USA

e-mail: tamar.smith-norowitz@downstate.edu

R. Joks

Department of Medicine, State University of New

York Downstate Medical Center, Brooklyn, NY, USA

H. G. Durkin

Department of Pathology, State University of New

York Downstate Medical Center, Brooklyn, NY, USA
$\mathrm{CD} 4+\mathrm{CD} 60+, \mathrm{CD} 8+\mathrm{CD} 60+)$, total serum IgG and IgE levels, and VZV-IgG, IgM, and IgE Ab levels were measured in a healthy girl (14 yearold) pre- and post-VZV re-immunization (weeks 1-8) [flow microfluorimetry, nephelometry, ELISA, enzyme immunoassay (EIA)].

Results: Pre-re-immunization numbers of $\mathrm{T}$ cells $(\mathrm{CD} 3+\mathrm{CD} 4+, \mathrm{CD} 3+\mathrm{CD} 8+, \mathrm{CD} 4+\mathrm{CD} 60+$, $\mathrm{CD} 8+\mathrm{CD} 60+)$ and $\mathrm{B}$ cells (CD19+) were within normal ranges. After re-immunization, numbers of $\mathrm{T}$ cells remained relatively unchanged; however, numbers of CD19+ B cells increased (48\%). Total serum IgG was low $(757 \mathrm{mg} / \mathrm{dl})$, and total serum IgE was normal (30 IU/ml). Prereimmunization, VZV IgG and IgM Ab levels were negative $(<0.90$ and $<0.90$ antibody index, respectively), and VZV IgE levels were undetectable. After re-immunization, VZV IgG Ab levels were positive (690.70 Ab index), VZV IgM Ab levels were negative $(\leq 0.90)$, and VZV IgE levels remained undetectable.

Conclusion: Vaccination with the VZV vaccine may boost IgG but not IgE-specific viral responses and concurrently increase the numbers of CD19+ B cells.

Keywords: CD19+ B cells; Immunization; Varciella zoster virus; Varicella zoster virus-IgG 


\section{INTRODUCTION}

Varicella-zoster virus (VZV) is a member of the Herpesviridae family and causes chickenpox (varicella) and herpes zoster (shingles) [1]. Chickenpox is highly contagious and causes acute infection [1]. This disease is characterized by a dermal vesiculopustular rash that develops 10-21 days following exposure [1]. Primary infection with VZV results in immunity from subsequent infection; VZV remains latent within sensory neurons and may subsequently reactivate, causing disease (herpes zoster) $[1,2]$. Herpes zoster is a painful condition that occurs in older non-immune adults or those with waning immunity to VZV and in patients with impaired cellular immunity [3].

Both humoral and cellular immune responses have been described in VZV [4]. Immunity to VZV consists of VZV-specific Abs and CD4 and CD8 T cells [5]. Harper and Grose [6] reported IgM and IgG responses to VZV p32/p36 polypeptide complex after chicken pox and zoster and in recipients of the VZV vaccine [6]. Previous studies in our laboratory demonstrated that IgE anti-VZV responses before, during, and after shingles [4] and peripheral blood lymphocyte CD23 expression were decreased during shingles and remained low after infection [4]. It has been suggested that IgE anti-viral responses might contribute to protective immunity in specific populations [4].

The Centers for Disease Control and Prevention (CDC) recommends two doses of chicken pox vaccine for children, adolescents, and adults [7], which has decreased yearly chicken pox cases from $13 \%$ to approximately $2 \%$ [7]. The decrease of varicella incidence is related to the efficacy of the vaccine, to the achieved coverage rate, and to the adopted twodose strategy.

VZV immunity could be measured evaluating both humoral (Ab titers) and cell-mediated immune responses [8]. However, measuring VZV IgG Abs may be challenging, especially for detecting Ab levels after immunization; serologic techniques may lack sensitivity and specificity [9]. There is not a universal consensus on an IgG level related to protection. Commercially available enzyme-linked immunosorbent assay (ELISA) tests are usually not considered adequate to measure immunity against VZV [9]; a glycoprotein (gp)-based ELISA is a more reliable test but is not commercially available.

Varicella vaccine failure is poorly understood, and currently there are no good diagnostic tools to differentiate primary vaccine failure versus failure to maintain protective $\mathrm{Ab}$ levels. Primary vaccine failure is defined as failure to mount a protective immune response after one dose of vaccine, and secondary vaccine failure is defined as a gradual loss of immunity after an initial immune response over a period of years after vaccination (waning immunity) [10]. Varicella immunity is an important issue because of ongoing cases and potential exposure of non-immune persons. The aim of the current study was to examine vaccine-induced humoral and cell-mediated immune responses in a patient with negative IgG VZV Ab status after two doses of varicella vaccine, before and after re-immunization.

\section{CASE DESCRIPTION}

\section{Patient Clinical Information}

A healthy 14-year-old female pediatric patient presented to our outpatient pediatric practice in Brooklyn, New York, because of possible VZV exposure in school; thus, her Ab levels were checked. The patient did not have a history of chicken pox infection and was up to date with her vaccines. The patient received the recommended two doses of the measles, mumps, rubella (MMR), and varicella virus vaccine (a 0.5-ml dose after reconstitution in a sterile diluent for subcutaneous injection) (ProQuad, Merck \& Co., Inc., Whitehouse Station, NJ, USA). The first dose (VARIVAX, Merck \& Co.) was administered at 14 months of age and a second dose (ProQuad, Merck \& Co.) at 4 years of age. The third dose (re-immunization) (VARIVAX, Merck \& Co.) was given at 14 years of age. Each dose is approximately $0.5 \mathrm{ml}$ after reconstitution in sterile diluent and is administered by subcutaneous injection. 
The patient was in good health and had no sick contacts or travel history.

Immunity to hepatitis B had been previously documented. The patient had no known history of asthma, allergies, atopic dermatitis, or allergic rhinitis; no other infections were noted in the patient's history. At the time of this study, the patient was not receiving any medications. Patient characteristics (pre-re-immunization) are listed in Table 1.

\section{Compliance with Ethics Guidelines}

Approval of this study was obtained from the SUNY Downstate Institutional Review Board. Informed consent was obtained from the child's parents, and the patient signed a consent form

Table 1 Participant characteristics pre-re-immunization

\begin{tabular}{ll}
\hline Age, years & 14 \\
Female & Yes \\
Total serum IgG (mg/ & 757 (range $842-2013 \mathrm{mg} / \mathrm{dl}$ ) \\
dl) & \\
Total serum IgE (IU/ & 30 (range 20-100 IU/ml) \\
ml) & \\
VZV IgG Ab (Ab & $<0.90$ (range $<0.91 \mathrm{Ab}$ index, \\
index) & negative) \\
VZV IgM Ab (Ab & $<0.90$ (range $\leq 0.90 \mathrm{Ab}$ index, \\
index) & negative) \\
VZV IgE Ab (OD & Not detected \\
value) & \\
Measles IgG Ab (AU/ & $<25.00$ (range $<25.00 \mathrm{AU} / \mathrm{ml}$, \\
ml) & negative) \\
Mumps IgG Ab (AU/ & 17.90 (range $>10.99$ index, \\
ml) & positive) \\
Rubella IgG Ab (Ab & $<0.90$ (range $<0.90 \mathrm{index}$, \\
index) & negative) \\
History of asthma & No \\
\hline
\end{tabular}

$\overline{V Z V \text { varicella zoster virus, } \operatorname{Ig} G \text { immunoglobulin } \mathrm{G}, \operatorname{Ig} E}$ immunoglobulin $\mathrm{E}$ for the use of her blood samples included in this study.

\section{Serology}

Peripheral blood samples $(5 \mathrm{ml})$ were collected pre- and post-re-immunization (weeks 1-6). Total serum IgG was determined by Quest Diagnostics, Inc. (nephelometry). Serum IgG and IgM Abs to VZV were determined by EIA (Quest Diagnostics, Inc.) Data are reported as ratios as follows: ranges for VZV Ab IgG: negative $<0.91$, positive $>1.09$; VZV Ab IgM: negative $<0.901$, positive $>1.09$. When post-reimmunization bloods were submitted to Quest (May 2017), the ranges for VZV IgG Abs changed to negative $<135.00 ; 135.00-164.99$ equivocal; $>165.00$ positive. Pre- and post-week 1 : IgG and IgM values: Quest Diagnostics (EIA). Post-week 2-8 IgG and IgM: SUNY Downstate (EIA). IgE: SUNY Downstate (ELISA). The presence of IgE anti-VZV Abs was determined by a modification of an ELISA using an IgG VZV ELISA kit (BioQuant, San Diego, CA), as previously described [4]. Serum IgG and IgM Abs to MMR were determined by EIA (Quest Diagnostics, Inc.).

\section{Flow Cytometric Analysis}

The Abs used in this study were: mouse antihuman monoclonal Abs conjugated to fluorescein isothiocyanate (FITC) (IgM anti-CD60) (Ancell; Bayport, MN), Simultest [FITC/phycoerythirn (PE)-conjugated reagents (CD3/CD4, CD3CD8, CD3CD19)] (BD Biosciences; San Jose, CA, USA), and appropriately matched isotype control Abs (FITC-conjugated IgM, Simultest control gamma 1 gamma $_{2 \mathrm{a}}$ ), as previously described [4].

\section{DIAGNOSTIC ASSESSMENT}

Prior to re-immunization, VZV IgG Ab levels were negative $(<0.90 \mathrm{Ab}$ index $)$ and VZV IgM $\mathrm{VZV} \mathrm{Ab}$ levels were also negative $(\leq 0.90 \mathrm{Ab}$ index) (Table 1), indicating either no prior exposure to VZV or lack of a specific immune 
response to immunization. However, 1 week post-re-immunization VZV IgG Ab levels were positive (690.70 Ab index) and VZV IgM Ab levels were negative ( $\leq 0.90 \mathrm{Ab}$ index) (Table 2$)$. For weeks 2-8, VZV IgG Ab was present $(+)$, while VZV IgM levels were negative $(-)$, except for week 8, where VZV IgM levels were positive (0.99 Ab index) (Table 2). In contrast, VZV IgE $\mathrm{Ab}$ levels were undetectable pre- and post-reimmuniztion (Table 2). Measles Ab IgG levels were $<25.00 \mathrm{AU} / \mathrm{ml}$ (range $<25.00$ negative, 25.00-29.99 equivocal, $>29.99$ positive). Mumps Ab IgG levels were $17.90 \mathrm{AU} / \mathrm{ml}$ (range $<9.00$ negative, 9.00-10.99 equivocal, $>10.99$ positive). Rubella Ab IgG levels were $<0.90 \mathrm{Ab}$ index (range $<0.90$ negative, $0.90-0.99$ equivocal, $\geq 1.00$ positive) (Table 1 ).

Pre-re-immunization, distributions of lymphocyte subpopulations (CD3+CD4+, $\mathrm{CD} 3+\mathrm{CD} 8+, \quad \mathrm{CD} 19+, \quad \mathrm{CD} 4+\mathrm{CD} 60+$,

Table 2 Varicella zoster virus IgG and IgE Ab levels preand post-re-immunization

\begin{tabular}{|c|c|c|c|}
\hline \multirow[t]{2}{*}{ Time } & \multicolumn{3}{|c|}{ Varicella zoster virus } \\
\hline & $\begin{array}{l}\text { IgG } \\
(\mathbf{A b} \text { index })\end{array}$ & $\begin{array}{l}\text { IgM } \\
\text { (Ab index) }\end{array}$ & $\begin{array}{l}\text { IgE } \\
\text { (OD value) }\end{array}$ \\
\hline Pre & $<0.90^{\mathrm{a}}$ & $<0.90$ & nd \\
\hline Post-week 1 & $690.00^{\mathrm{b}}$ & $<0.90$ & nd \\
\hline Post-week 2 & + & $<0.90$ & nd \\
\hline Post-week 3 & + & $<0.90$ & nd \\
\hline Post-week 4 & + & $<0.90$ & nd \\
\hline Post-week 5 & + & $<0.90$ & nd \\
\hline Post-week 6 & + & $<0.90$ & nd \\
\hline Post-week 8 & + & $0.99^{\#}$ & nd \\
\hline
\end{tabular}

Varicella zoster virus (VZV) IgG, IgM and IgE Ab levels in the serum of a pediatric patients with negative IgG VZV $\mathrm{Ab}$ status before (pre) and post (weeks 1-8) re-immunization with live varicella virus vaccine (VARIVAX, Merck \& Co., Inc). Data are expressed as the Ab index (IgG and $\operatorname{IgM}$ ) or OD value (IgE). Pre- and post-week 1: IgG and IgM values: Quest Diagnostics (EIA). Post-week 2-8 IgG and IgM: SUNY Downstate (EIA). IgE: SUNY Downstate (ELISA)

nd not detectable

${ }^{a}$ High laboratory value

${ }^{b}$ Low laboratory value
$\mathrm{CD} 8+\mathrm{CD} 60+)$ in the peripheral blood of the patient were all within normal ranges (Table 1). However, post-re-immunization (4 weeks), numbers of $\mathrm{T}$ cell subpopulations remained unchanged, while CD19+ B cells increased 48\% (Table 2). Post-re-immunization (8 weeks), the numbers of $\mathrm{T}$ cell subpopulations remained unchanged, while the numbers of CD19+ B cells decreased slightly (6\%) (Table 3).

\section{THERAPEUTIC INTERVENTION}

No further interventions indicated.

\section{FOLLOW-UP AND OUTCOME}

No repeat titers or follow-up was indicated at this time. A potential indication for repeat titers would be pregnancy or high-risk exposure. The outcome is a protective immune response.

\section{DISCUSSION}

In humans, humoral and cellular immune responses are inducible by vaccines for infectious diseases $[4,6,11]$. However, some individuals may experience weaker than expected immunologic responses than others. The diagnosis of primary varicella virus infection can be made by demonstrating seroconversion from negative to positive specific IgG antibody response or by detecting virus-specific IgM $[1,9]$. In the current study, we found that rapid (1 week) post-re-immunization VZV IgG responses were observed and the numbers of blood CD19+ B cells increased. Specific IgE VZV responses were not observed, indicating that $\operatorname{IgE}$ responses to the VZV vaccine are not a universal phenomenon but may represent responses observed only in selected individuals or at specific time points following immunization not captured by our study. Previous studies in our laboratory demonstrated the existence of IgE anti-VZV Abs and long-term persistence of IgE anti-VZV in pediatric and adult serum postchicken pox infection and after vaccination with the VZV vaccine [12]. 
Table 3 Distributions of lymphocyte subpopulations in peripheral blood before and after reimmunization with varicella zoster virus vaccine

\begin{tabular}{|c|c|c|c|c|c|c|c|c|c|c|c|c|}
\hline \multirow[t]{2}{*}{ Time } & \multicolumn{2}{|c|}{ CD3+ } & \multicolumn{2}{|c|}{$\mathrm{CD} 3+\mathrm{CD} 4+$} & \multicolumn{2}{|c|}{$\mathrm{CD} 3+\mathrm{CD} 8+$} & \multicolumn{2}{|c|}{$\mathrm{CD} 4+\mathrm{CD} 60+$} & \multicolumn{2}{|c|}{$\mathrm{CD} 8+\mathrm{CD} 60+$} & \multicolumn{2}{|c|}{ CD19+ } \\
\hline & $\overline{(\%)}$ & $\overline{\mathrm{mm}^{3}}$ & $\overline{(\%)}$ & $\mathrm{mm}^{3}$ & $\overline{(\%)}$ & $\mathrm{mm}^{3}$ & $\overline{(\%)}$ & $\mathrm{mm}^{3}$ & $\overline{(\%)}$ & $\mathrm{mm}^{3}$ & $\overline{(\%)}$ & $\overline{\mathrm{mm}^{3}}$ \\
\hline Pre & 79 & 1531 & 35 & 686 & 24 & 461 & 13 & 257 & 3.3 & 64 & 11 & 218 \\
\hline Post: 4 weeks & 74 & 1432 & 37 & 727 & 25 & 484 & 13 & 257 & 2.8 & 54 & 17 & 323 \\
\hline Post: 8 weeks & 77 & 1502 & 38 & 742 & 25 & 484 & 14 & 270 & 2.7 & 53 & 16 & 305 \\
\hline
\end{tabular}

The distributions of lymphocyte subpopulations in peripheral blood of a pediatric patient with negative IgG varicella zoster virus antibody status before (pre) and post ( 4 and 8 weeks) re-immunization with live varicella virus vaccine (VARIVAX, Merck \& Co., Inc). Data are expressed as mean total cells $/ \mathrm{mm}^{3}$ or mean percentage (\%) of positive cells

This case demonstrates that in a subgroup of people, the $\mathrm{Ab}$ response to vaccination with VZV may be low despite normal cell-mediated responses. Prior literature has reported persistent serologic non-response to VZV immunization in a patient with adequate cellular response [13]. Since currently utilized ELISA screening tests are variabile, ELISAs with greater sensitivity are necessary. When VZV Ab levels are low, assays that test cellular responses (lymphocyte proliferation assays or commercial assays not available) should be used.

The accepted standard for identifying VZV vaccine responses or prior disease exposure is measuring the IgG Ab titer [13]. Other varicella $\mathrm{Ab}$ assays include: complement fixation, indirect immunofluorescent assay (IFA), radioimmunoassay (RIA), LA, and ELISA [13]. These assays are sensitive and can detect $\mathrm{Ab}$ to natural infection, but a level of variability exists in detecting $\mathrm{Ab}$ levels after vaccination [14]. It has been speculated that the VZV Ab response after immunization with the VZV vaccine (live-attenuated) is lower ( $>$ tenfold) than after natural infection [15].

In our patient, who had been previously vaccinated with two doses of VZV vaccine (> 10 years), pre-re-vaccination IgG-anti VZV Ab levels were negative $(<0.90$ antibody index $)$ and IgM anti-VZV Ab levels were also negative $(<0.90$ antibody index), indicating either no prior exposure to VZV or a lack of a specific immune response to immunization. These results may indicate that evaluation of positive immune status through detection of IgG VZV antibody responses after vaccination may not be sufficient. Often, it is important to assess the varicella immunity status of adolescents and adults and vaccinate those who lack evidence of varicella immunity [16]. If immunity needs to be determined, but the IgG in serum is below the cutoff for immunity, a cellular immune response assay or rechecking IgG following a booster immunization is recommended [16].

Vaccine-mediated immunity is complicated [17]. A vaccine stimulates specific Abs; protection depends on the amount of vaccine-induced $\mathrm{Ab}$ and the quality of the response (antigen-binding avidity) [17]. B cell responses to a vaccine are mediated by $\mathrm{T}$ cells, which are important for longterm immunologic memory [17]. The innate immune system responds to molecules associated with pathogens and host cell damage (pathogenassociated molecular patterns) [18]. In addition, cytokines produced by innate cells can activate adaptive immune responses (e.g., proliferation, cytokine or $\mathrm{Ab}$ production by $\mathrm{T}$ and $\mathrm{B}$ cells) [18].

In specific individuals, contributory factors and/or causes associated with VZV seronegative status may include waning $\mathrm{Ab}$ responses or vaccine failure. Waning of vaccine-induced $\mathrm{Ab}$ levels can be expected and has been reported in certain vaccinated adults (MMR vaccine) [19]. However, the current findings have confirmed previous observations regarding the relationship between the primary $\mathrm{Ab}$ response to the varicella vaccine and protection against varicella disease [20].

It should also be mentioned that our patient received two doses of MMR vaccine, but had negative responses for measles and rubella. Although the MMR vaccine is efficacious ( $\sim 90 \%)$, vaccine failure or loss of immunity after one or two doses of vaccine has been documented [21]. It has been reported that 15\% 
of people do not develop Ab titers to one or more of the components of MMR after a single dose; after two doses, about $2 \%$ will still not have positive titers [21]. It can be speculated that in our patient, this may be due to suboptimal cell-mediated immune responses against the measles and rubella vaccine or perhaps due to fewer virus-specific T cells.

In humans, responses to infectious diseases or vaccines depend on many different cell populations and interactions between different cell populations [22]. In the current study, we also observed that post-booster immunization, the numbers of $\mathrm{T}$ cell subpopulations remained unchanged but the numbers of CD19+ B cells were increased (by $48 \%$ ) in blood (4 weeks postimmunization). This may indicate stimulation or maintenance of memory B cells. B cells play multiple important roles during the induction of immune responses to vaccines [23] and also have regulatory functions. They can act as antigen-presenting cells or effector cells (which produce Abs, cytokines, and chemokines) [24-26]. Since there was an increase in the number of circulating CD19+ B cells after reimmunization, this effect may be due to increased activation of $\mathrm{B}$ cells in lymphoid tissue. It could also be that memory B cells and their response to vaccination may be less predictable than previously thought. Primary nonresponders have a $\mathrm{T}$ cell deficiency, but secondary vaccine deficiencies (as observed in this study) are less well understood. Since the numbers of $\mathrm{T}$ cells did not increase in our patient, it could be speculated that a lack of a robust $\mathrm{T}$ cell memory response may indicate the underlying pathology of secondary vaccine failure.

\section{CONCLUSION}

Understanding the immune mechanisms that underlie the successful generation of immune memory responses after VZV vaccination has remained a challenge and has significant implications for the management of vaccine non-responders. Further studies are necessary to investigate new strategies to improve vaccine responses.

\section{ACKNOWLEDGEMENTS}

Funding. No funding or sponsorship was received for this study or publication of this article. The article processing charges were funded by the authors.

Authorship. All named authors meet the International Committee of Medical Journal Editors (ICMJE) criteria for authorship for this article, take responsibility for the integrity of the work as a whole, and have given their approval for this version to be published.

Disclosures. Tamar A. Smith-Norowitz, Tehila A. Saadia, Kevin B. Norowitz, Rauno Joks, Helen G. Durkin, and Stephan Kohlhoff have nothing to disclose.

Compliance with Ethics Guidelines. Approval of this study was obtained from the SUNY Downstate Institutional Review Board. Informed consent was obtained from the child's parents, and the patient signed a consent form for the use of her blood samples included in this study.

Data Availability. All data generated or analyzed during this study are included in this published article.

Open Access. This article is distributed under the terms of the Creative Commons Attribution-NonCommercial 4.0 International License (http://creativecommons.org/licenses/ by-nc/4.0/), which permits any noncommercial use, distribution, and reproduction in any medium, provided you give appropriate credit to the original author(s) and the source, provide a link to the Creative Commons license, and indicate if changes were made.

\section{REFERENCES}

1. Yankowitz J, Grose C. Congenital infections. In: Storch GA, editor. Essentials of diagnostic virology. New York: Churchill Livingstone; 2000. p. 187-201. 
2. Lungu O, Panagotidis CA, Annunziato PW, Gershon AA, Silverstein SJ. Aberrant intracellular localization of varicella-zoster virus regulatory proteins during latency. PNAS USA. 1998;95:7080-5.

3. Gnann JW Jr, Whitley RJ. Clinical practice. Herpes zoster. N Engl J Med. 2002;347:340-6.

4. Smith-Norowitz TA, Josekutty J, Lev-Tov $H$, Kohlhoff S, Norowitz KB, Silverberg JI, Chice S, Durkin HG, Bluth MH. IgE anti-varicella zoster virus and other immune responses before, during, and after shingles. Ann Clin Lab Sci. 2009;39:43-50.

5. Arvin AM, Sharp M, Moir M, et al. Memory cytotoxic $\mathrm{T}$ cell response to viral tegument and regulatory proteins encoded by open reading frames 4,10 , 29 , and 62 of varicella-zoster virus. Viral Immunol. 2002;15:507-16.

6. Harper DR, Grose C. IgM and IgG responses to varicella-zoster virus p32/p36 complex after chickenpox and zoster, congenital and subclinical infections, and vaccination. J Infect Dis. 1989;159:444-51.

7. Centers for Disease Control and Prevention. Prevention of varicella: recommendations of the Advisory Committee on Immunization Practices (ACIP). MMWR. 2007;56(RR-04):1-40.

8. Saiman L, LaRussa P, Steinberg S, et al. Persistence of immunity to varicella-zoster virus vaccination among health care workers. Infect Control Hosp Epidemiol. 2001;22:279-83.

9. LaRussa P, Steinberg S, Waither E, Hanna B, Holzman R. Comparison of five assays for antibody to varicella-zoster virus and the fluorescent-antibodyto-membrane-antigen test. J Clin Microbiol. 1987;25:2059-62.

10. Michalik DE, Steinberg SP, LaRussa PS, et al. Primary vaccine failure after 1 dose of varicella vaccine in healthy children. J Infect Dis. 2008;197:944-9.

11. Amanna IJ, Carlson NE, Slifka MK. Duration of humoral immunity to common viral and vaccine antigens. N Engl J Med. 2007;357:1903-15.

12. Smith-Norowitz TA, Josekutty J, Silverberg JI, et al. Long term persistence of IgE anti-varicella zoster virus in pediatric and adult serum post chicken pox infection and after vaccination with varicella virus vaccine. Int J Biomed Sci. 2009;5:353-8.

13. Katial RK, Ratto-Kim S, Sitz K, Moriarity R, Engler RJM. Varicella immunity: persistent serologic nonresponse to immunization. Ann Allergy Asthma Immunol. 1999;82:431-4.
14. Wreghitt TG, Tedder RS, Nagington J, Ferns RB. Antibody assays for varicella virus: comparison of competitive enzyme-linked immunosorbent assay (ELISA), competitive radioiommunoassay (RIA), complement fixation, and indirect immune-fluorescence assays. J Med Virol. 1984;13:361-70.

15. Krah DL. Assays for antibodies to varicella-zoster virus. Infect Dis Clin N Am. 1996;10:507-27.

16. American Academy of Pediatrics. Committee on infectious diseases. Varicella Vaccine Updatea. Pediatrics. 2000;105:136-41.

17. Meissner HC. Vaccines protect against disease in remarkably diverse ways. AAP News. 2017;38:8.

18. Sherrid AM, Ruck CE, Sutherland D, Cai B, Kollmann TR. Lack of broad functional differences in immunity in fully vaccinated vs. unvaccinated children. Pediatr Res. 2017;81:601-8.

19. Kontio M, Jokinen S, Paunio M, Peltola H, Davidkin I. Waning antibody levels and avidity: implications for MMR vaccine-induced protection. J Infect Dis. 2012;206:1542-8.

20. White CJ, Kuter BJ, Ngai A, et al. Modified cases of chickenpox after varicella vaccination: correlation of protection with antibody response. Pediatr Infect Dis J. 1992;11:19-23.

21. CDC. Measles, mumps, and rubella-vaccine use and strategies for elimination of measles, rubella, and congenital rubella syndrome and control of mumps: recommendations of the Advisory Committee on Immunization Practices ACIP. MMWR. 1998;47(8):1-57.

22. Wang C, Liu Y, Cavanagh MM, et al. B-cell repertoire responses to varicella-zoster virus vaccination in human identical twins. Proc Natl Acad Sci USA. 2015;112:500-5.

23. Porakishvili NR, Mageed C, Jamin JO, et al. Recent progress in the understanding of B-cell functions in autoimmunity. Scand J Immunol. 2001;54:30-8.

24. Silverman GJ, Carson DA. Roles of B cells in rheumatoid arthritis. Arthritis Res Ther. 2003;5(Suppl 4):S1-6.

25. Anderton SM, Filatreau. Activated B cells in autoimmune diseases: the case for a regulatory role. Nat Clin Pract Rheumatol. 2008;4:657-66.

26. Kessel AT, Haj R, Peri A, et al. B regulatory cells suppress proliferation of CD4+ T cells and enhance Foxp3 and CTLA-4 expression in T-regulatory cells. Autoimmun Rev. 2012;11:670-7. 